\title{
Linguistic Creativity and Genre Characteristics in the Media Discourse
}

Cosmina STROINEA ${ }^{1}$

\begin{abstract}
Changes in communication have been fueled by the evolution of the internet as a platform for interaction as well as by other technological advancements. Thus, the aim of the present study is to analyze the media discourse used within different genres in the online context. The hypothesis I started from is that depending on the author's assumptions regarding the audience, there will be differences at various levels between genres (such as the stylistic level, the microstructure and macrostructure levels, and the morphological and syntactical levels). The analysis conducted might help researchers gain new perspectives on the changes that are taking place in the field of communication in the media.
\end{abstract}

Keywords: media discourse; genre analysis; discourse analysis; corpus linguistics.

DOI: $10.24818 / D L G / 2021 / 38 / 07$

\section{Introduction}

7 The main focus of this study is on economic and coronavirus-related news, so as to observe the choice and adaptation of linguistic means according to each of the channels used for broadcasting by Prague Morning (Official website, Facebook page and Twitter) and to the expected readership. As stated on its official Facebook page, Prague Morning is Czech Republic's leading media outlet in English. Therefore, the center of interest will be on three different genres: tweets, Facebook posts, and online articles (published on the official website of the media outlet).

As concluded after a short analysis, the audiences of these genres vary in size and do not completely overlap, but to some extent they share a common element, i.e., they speak the same language. As one can notice, the media outlet is of Czech origin, but the language of use is English. A conclusion that can be drawn from this is that the news is intended for foreign audiences such as expats ("Expat Next Door" \& "Lifestyle"

\footnotetext{
${ }^{1}$ Cosmina Stroinea, Modern Applied Languages Graduate, Bucharest University of
} Economic Studies, stroinea.cosmina@gmail.com 
sections), international students, exchange students, foreign investors ("Real Estate" \& "Politics and economics" sections) and tourists ("Travel" section).

To confirm the hypothesis I started from, I assembled a corpus of texts including sample texts from all three genres which will be analyzed:

A. Tweets (hereinafter referred to as " $\mathrm{A}$ "-Corpus)

B. Facebook posts (hereinafter referred to as "B"-Corpus)

C. Online articles (hereinafter referred to as " $\mathrm{C}$ "-Corpus)

When selecting the corpora to be analyzed, two criteria have been taken into consideration:

1. The span of time (all news have been broadcasted between January and April 2021)

2. Topic (of current interest - the COVID-19 pandemic, economic interest, and other subjects)

All text samples have been taken over a specific span of time to analyze the news broadcasted from the beginning of the year. I selected texts on common topics (i.e., politics, economics, the COVID-19 pandemic) as well as other subjects, to observe what Prague Morning chooses to publish on different channels of communication. The articles have been chosen from the field of economics and politics (decisions of politicians regarding the pandemic, as well as its effects on the Czech economy). The Facebook posts and tweets regard both the pandemic and news on cultural, sports, culinary, travel topics and others, as there are no separate sections for each (comparing to the website). To justify a comparison between the three genres, some of the news samples are found on all three platforms and will be studied in parallel so as to display the differences in discourse across different genres.

Throughout this study I will use Newman's 2011 study" Mainstream media and the distribution of news in the age of social discovery", and O'Keeffe's 2011 "Media and discourse analysis" and "The media" research studies as points of reference to see to what extent my results converge with the authors'. The former aims at analyzing how the rise of social media (especially Facebook and Twitter) determined changes in communication and addresses the issues of these media affecting businesses in the field of traditional journalism. It is based on interviews of numerous professionals in this area and it explores this topic not only in the West, but also in the Eastern World. On the other hand, O'Keeffe's studies look at how technological advances led to written news adopting a 
spoken aspect of communication. The last part of the study will consist in a comparison between Prague Morning's articles and Mureșan's (2000) analysis of financial articles to establish similarities and dissimilarities between the two corpora.

\section{Methodology}

The methodology of this study includes different approaches aimed at studying the selected corpus from multiple angles. It comprises 25 articles, 58 Tweets and 54 Facebook posts selected manually over a span of four months (January-April 2021), totaling 11.205 words and 2566 word types. One of the methods used for this research is genre analysis, which I employed as a tool to look at how Prague Morning adapts the content and form of its published news according to the discourse community towards which the news is directed, as well as according to the level of formality on each news channel and to the allowed length of the text (limited to 140 characters in the case of Twitter). Another tool used is discourse analysis, which acted as a lens through which I could look closely at the language used within the corpora, especially at what kind of pronouns and reporting verbs the author uses and what the communicative function of these are. Finally, corpus based analysis complemented these two approaches, allowing me to see the frequency of words used within the corpora, which helped me to further determine their content. I used the studies of Newman (2011) and O'Keeffe (2011a; 2011b) as points of reference to see how language and communication in the media have evolved since the rise of social media and other technological advancements as well as to be able to determine to which extent the changes that communication has undergone apply to Prague Morning's news.

\section{Frequently approached issues in the media}

\section{Language and ideology}

Scholars like Van Dijk (1997), O'Keeffe (2011b), O'Halloran (2010), Fairclough (2000) and McQuail (1994) have identified a connection between language and ideology and almost all of them seem to agree that language use is linked to the concepts of power, domination and inequality in society. 
The spoken aspect of the media language in nowadays communication

Media have changed to make discourse more interactive and that can be seen at both the level of traditional media and social media. O'Keeffe (2011a) makes a comparison between language use before and after the rise of technology. In another study, she points out that "we now see a greater level of intertextuality and a blurring of the lines between spoken and written media"' (O’Keeffe, 2011b, p.76).

After having analyzed some interactions from social networking sites, O'Keeffe (2011a) concludes that the way in which language is made use of resembles spoken interactions rather than written texts, mostly due to the use of emoticons and to the lack of consideration concerning grammar rules. She adds that compared to spoken communication, posts can be read and responded to for an indefinite time after they have been published and that even though these interactions seem to imitate face-toface conversations, they do not always happen in real time. O'Keeffe believes that the media has evolved to become the public's media, as we can now interact directly with what is published or broadcast, and we can provide feedback. Moreover, instead of having to search for the news, it finds us instead. The studies conclude that the rise of technologies led to changes in the way people communicate, share the news, react to it and consume it, as well as in what concerns the relationships that take shape between the authors and the wider audience. These changes include the shift from a formal aspect of written media to a more informal, spoken tone of it that facilitates communication and interaction.

It seems that even professionals prefer this style as it is less pretentious. Gideon Rachman, a Financial Times blogger, prefers writing blogs rather than columns because they are easier and faster to write and because they have a more informal tone. He compares it to composing an email for someone from his family and enjoys the fact that blogs do not need subediting or other forms of checks (Newman, 2011).

O'Keeffe (2011a) also believes that it is an interesting period to study media discourse since all the variables are altering, and she adds that discourse analysts find themselves challenged to adapt and find new ways of approaching these emerging patterns in such a way that they include the enlarged barriers of interactions. 
Does the content have to adapt to consumer demand?

Some studies affirm that new media content is shaped to fit customers' expectations and demands, and this is both seen as a positive and a negative aspect that might affect journalists. The Economist's Tom Sandage believes that journalists' discernment has not necessarily been altered by the public's needs and wishes, but he thinks the advent of the internet allowed an extension of the topics addressed in this field, which means they must be flexible and adapt to these changes in order to keep being relevant on the market (Newman 2011).

On the other side, in the study, "What's happening to our news", researcher Andrew Currah observed how certain publishers run the risk of turning into "digital windsocks" (Newman, 2011, p. 25), in a world where audiences dictate the course the news will take. This is how, he adds, they may have to give up their individuality. News journals such as The Telegraph, The Times and The Guardian created segments to fit the popular demand (i.e., Lifestyle, Celebrity, Weird) (Newman 2011).

Will social media render traditional journalism obsolete, or should they work hand in hand?

There is fear that traditional forms of media will become obsolete as a source of new information due to the rise of Facebook and Twitter. According to the 2011 study conducted by Newman at the Reuters Institute for the Study of Journalism, some United Kingdom-based companies highlighted that higher traffic derives from social media platforms rather than from search, while in the United States, Mashable.com logfiles confirm this fact, after having noticed that Facebook and Twitter visitors spent $29 \%$ more time on the website and accessed $20 \%$ more pages than visitors using search engines.

Washington Post's Raju Narisetti says that YouTube, Facebook and Twitter do not generate new information, but their success resides in the fact that they convey news in a practical and appealing manner, at the same time bringing the public relevant information (Newman, 2011). Author Nic Newman mentions that evidence gathered by Tweetminster indicates that "two emerging news organizations" have gained importance thanks to social media, those being the Arabic company Al Jazeera and an organization now owned by MSNCB.

After analyzing different professionals' perspectives, the author of the study concludes that conventional journalism will not become obsolete 
because we need someone to create, "package" (Newman, 2011, p. 56) and share content of a high quality. Apart from that, he also reaches the conclusion that social media rather purifies and helps to amplify the news content coming from traditional forms of media, the two working more effectively together.

\section{Rhetorical questions}

The use of rhetorical questions is prevalent across the corpora, and it attracts attention to the subject of the message, while the inclusion of a rhetorical headline improves the effectiveness of the persuasive factor. Simultaneously, headlines that include questions are more successful than those with a declarative aspect when it comes to sparking the interest of the audiences (Lai \& Farbrot, 2014). Petty, Cacioppo and Heesacker (1981, p. 432) found a correlation between the use of rhetorical questions and the "cognitive elaboration of a message" and intensified "thinking", causing the content to be more convincing. As ascertained by Boler and Davis (2021, p. 233), research on this topic proved that headlines which involve rthetorical questions attract the attention of the public and enhance the level of "retweetability" of a message, which therefore increases the extent to which this gains "exposure".

Some examples of rhetorical questions are "Thoughts?" (as addressed at the end of a Facebook post in order to engage the audience) and "What are the advantages of raising a multilingual child in Prague?" (followed by a post in which the explanation is given).

\section{Findings and discussion}

Before going into details regarding each platform, it must be mentioned that the content shared through the three distinct channels is approximatively the same, the only differences concerning the way in which they are adapted to fit these channels and the expectations of the readers according to where they find their news. 


\section{Twitter}

At a first glance, it can be easily noticed that Prague Morning has significantly fewer followers on Twitter (3.5k) than on Facebook (218k), and therefore posts on the latter receive far more attention and participation from readers. Prague Morning's Twitter account often retweets helpful, visual infographics, allowing its followers to see third-party news, which can enhance the public's engagement with the news. Sometimes videos are included on Facebook and Twitter, being more common on the latter.

Tweets from Prague Morning mostly seem to have the role of updating the population on the ongoing pandemic situation, as many of them contain numbers that describe the rise in cases comparing to the previous week. Some Tweets convey news about how the Czech Republic intends to buy vaccines from Russia, which is a sign that the two countries are still close, especially since the Czech president is pro-Russian. He also made a call to China for getting more vaccines, which shows his sympathy for the socialist regimes. However, diplomatic ties between the Czech Republic and Russia have been severed after the event related to the expulsion of diplomats.

Nevertheless, Prague Morning does not only tweet about political and economic subjects, addressing topics such as culture, travel (by posting updated Covid-19 maps), and even events taking place in Prague.

Twitter's reliability has been questioned by some critics, but others seem to praise it as a source of information. For instance, for $B B C$ Social Media Editor Alex Gubbay, Twitter constitutes a main source of news (Newman, 2011). On Twitter, the journal posts mostly short pieces of news that only convey the essential information in a dense manner, while the readers should access the website for details.

\section{Emojis}

Posts on Prague Morning's Facebook and Twitter pages mostly utilize emojis and short sentences (usually one to two sentences) to describe a news topic which, according to Granato (2002), could have the role of attracting the reader's attention. The use of emojis on Twitter intends to convey emotions that cannot be transmitted in writing only. This opinion is confirmed by Roele, Ward \& van Duijn (2021, p. 2), who conclude that emojis are "tools" that help computer-mediated communication go beyond 
its own "limitations" when it comes to creating impressions and relationships, as well as by Newman (2011) who states that the news that social media users share seems to imply emotions and to have an atypical character. Prague Morning's emojis convey the topic of the post, being representative for the subject described. For instance, when writing about the rise in COVID-19 cases, the journal will use an emoji depicting a chart with a rising red line on it. Emojis also seem to set the tone of the post, transmitting a serious attitude about the Coronavirus pandemic situation by using a face covered with a mask on one side, and a smiley face when posting about a cheerful topic, on the other side. In the context of the pandemic, the most used emojis depicted the wearing of a facemask and the vaccine syringe.

\section{Hashtags}

Tweets also include hashtags of keywords, which render information on certain topics easier to find and encourage its exploration. This is confirmed by Michelle Zappavigna's article "Ambient affiliation: a linguistic perspective on Twitter" (2011) where she says that hashtags help bring together readers interested in the same subjects, as these work by categorizing conversations based on their topic (Shapp, 2014). Hashtags and emojis represent affordances of the internet. While the first can redirect the readers to similar topics which could be of interest for them, emojis are a practical way of transmitting the feelings and emotions people experience, being a positive result of the emergence of the internet and social media.

\section{Comparisons with Slovakia}

As comparisons with Slovakia appear across all corpora, here are some examples that appear on Twitter about updates on the Coronavirus situation in the country and about a discovery connected to the Czech president made by the Slovak National Memory Institute.

Table 1. Comparisons with Slovakia on Twitter. Prague Morning

\#Slovakia tightened lockdown and extended it till Feb. 7, as it launched a weeklong testing campaign.

A discovery by the Slovak National Memory Institute (UPN) has presented evidence that PM Babiš was indeed an agent of the StB. 
\#Slovakia will open shops in a limited capacity for customers with negative \#COVID19 tests as part of an easing of pandemic restrictions from next week, Finance Minister Igor Matovič said on Tuesday.

The media outlet's comparisons with Slovakia may suggest that the Czech Republic still feels solidarity towards its former other half, being a manifestation of the ideological dimension of language.

The pronoun "you"

Prague Morning often utilizes the second person, singular pronoun "you", a discursive technique which increases attention and participation, placing the reader in a closer and more personal relationship with the author. One post which includes it is the following:

A1: "Riegrovy is great, but maybe you want a little more peace? Here you can find 6 less-crowded parks for a spring stroll in \#Prague"

The use of this pronoun represents proof that language has indeed become more informal and has started to resemble spoken communication more and more, in line with O'Keeffe's (2011a) conclusions.

\section{Facebook}

When it comes to Facebook, as in the case of Twitter, each post is accompanied by a picture, a visual aspect which undoubtedly helps to get more attention from the audience, and by a catchy title, intended to make the reader stop from scrolling. Every Facebook post has a title that sums up its topic, and a description which provides more details. However, the full article must be accessed on the website for the reader to be able to find out more. Facebook offers a direct link to the official website, while Twitter does not have this option, which seems to be a limitation of the latter platform. However, even if Twitter posts cannot redirect the reader to the website, some Tweets include a link to various companies' sites, if these are approached in the respective post.

Facebook posts promote different topics of interest such as learning languages, Czech traditions, and even expats (by posting them and a short description of what they do and where they come from) and it also has a section called "News in brief", which summarizes the most recent events in a single post, making it easier for the audience to keep themselves informed. 


\section{Emojis}

As well as in Twitter's case, Facebook posts are accompanied by emojis describing the topic the post will introduce. Most of them are the same as on Twitter, since Prague Morning publishes the same content on all its platforms, adapting it to the conventions of each one of them. In this case, a form of adaptation is the very use of emojis, which cannot be included on the journal's website.

\section{Humour}

What is also interesting is that Prague Morning seems to have a sharp sense of humour and sarcasm, illustrated in a number of posts across the timespan chosen.

$B_{1}$ : One post depicted a police car with two kegs of beer in the back and the description which accompanied it was "Law \& order. Better with some beer".

$\mathrm{B}_{2}$ : Another funny caption was" Czechs know that morning exercise is important for health" on a compilation of pictures of people skiing on the streets of Prague in February 2021.

$\mathrm{B}_{3}$ : The outlet also posted a video of a man who crossed the metro rails and then could not climb the platform when he reached the opposite side, to which it added the comment: "The Man of the Day: a 20-year-old crossed the tracks at Cerny Most metro station. Then, he couldn't climb back up to the second platform. Finally, he was saved by...two police officers."

"In Myers's account, humour is seen, (after Brown and Levinson, 1987) as a positive politeness strategy, signalling that the other is a member of the same community as the speaker, with shared wants, and so on. (...) By sharing a joke with someone, we imply a degree of intimacy, at least conventionally, but, more than that, we suggest that we share similar tastes, world knowledge and cultural conventions, and we flatter the other by suggesting that he or she is clever enough to get the point of the joke" (Bloor,1996, p. 35).

Apart from the function cited above, the use of humour in this case is justified by the audience comprised mostly of young foreign people who are open-minded enough to savour jokes without taking them personally. 
The pronoun "you"

The pronoun form "you" can also be noticed on the Facebook page, not only on Twitter, serving the same communicative function.

$\mathrm{B}_{4}$ : "Hairdressers to open on 3 May. The news everyone has been waiting for. However, you need to show a negative test-either PCR or antigenic-in order to have your hair done"

\section{Twitter vs. Facebook}

On Twitter, even if the posts are similar to the content found on Facebook, there are some differences:

1. Prague Morning seems to use Twitter more as a platform to provide breaking news. Therefore, some tweets are purely informative and do not include any images, emojis or long descriptions. One example is the one below:

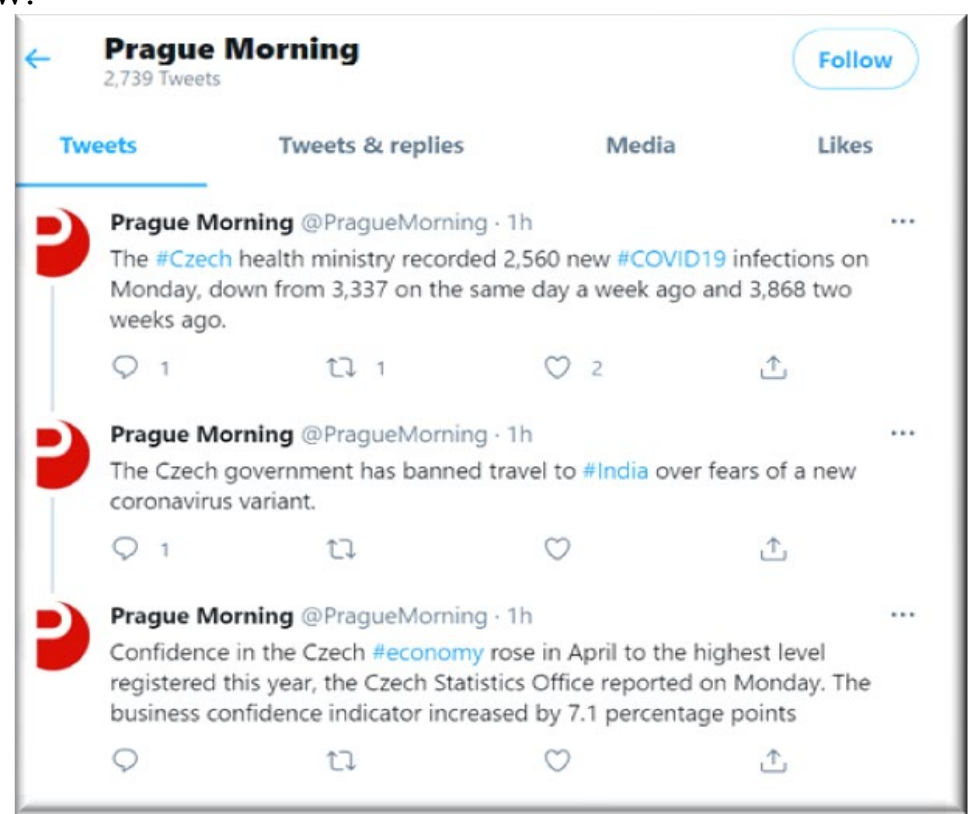

Figure 1. Tweets with a purely informative function. Prague Morning

2. Some posts on Twitter are a bit shorter than those on Facebook, which could be due to:

a) the character limit of Twitter (up to 140)

b) Twitter's nature as a microblogging platform, to which Prague Morning is trying to shape its posts 
Two contrasting examples can be seen below:

Example1:Example2: “On this day giant of Czech history Tomás Garrigue Massaryk was born, March 7, 1850

Example2: Today is the 171st anniversary of the birth of Tomás Garrigue Masaryk, founder and first president of Czechoslovakia and one of the most important figures in Czech history. He was actively involved in the establishment of the Czechoslovak Legion and toward the end of the Great War succeeded in winning backing in the US for a new Czechoslovak state, which was declared in October 1918. The "president liberator", as he came to be known to many Czechs, remained head of state until late 1935" (Facebook)

While the Twitter post only gives the core information supported by numbers to create an image of the proportions of the mortgage market evolution, the Facebook post goes into details about the personality it celebrates, giving a short presentation and background of the topic. The limited character number of Twitter impedes the use of details, which are instead published on other platforms, a way in which communication is adapted to its medium of communication.

\section{Articles}

The full-length articles are found on the website, expounding upon the short items of news from the social media pages. They are generally short, concise articles of about 200-400 words each, which convey information more succinctly and easier for the reader, while quotations from relevant figures are included to enhance credibility. Images and videos feature once again with the same aim of increasing engagement and attracting attention. In what concerns the amount of information given and the compactness of the content, the hierarchy looks

Articles

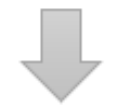

Twitter

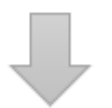

Facebook posts as follows (from the most detailed to the least detailed):

Figure 2. The hierarchy of platforms according to the compactness of the message 
This section is based on the analysis of a corpus of 25 articles, with a focus on the way they are structured at the macro- and micro-structure levels. The analysis includes the moves that help build the articles, the order in which they occur and the pattern that they contribute to constructing: either from general to particular or the other way around. At the same time, at the micro-structure level I analyzed the way in which statements from different sources are reported and which verbs are used, what pronouns are present and what their communicative function is as well as what patterns appear in terms of content (here, comparisons with Slovakia and other neighbouring countries). The analysis is followed by Mureșan's 2000 study of British economic articles with the aim of identifying similarities and differences.

\section{The macro-structure of articles}

It can be noticed that at the macro-level structuring of articles, certain moves are distinguished. Each chapter is composed of a title stating the topic, followed by a paragraph in bold providing additional information and context to the title, and the main part of the text whose length can vary from around 5 to approximately 11 paragraphs or even more. The string of moves identified as common in the corpus of articles comprises the following:

Table 2. Moves in Prague Morning's articles

\begin{tabular}{|l|l|}
\hline \multicolumn{2}{|c|}{ Moves always present } \\
\hline Move 1 & Breaking the news \\
\hline Move 2 & $\begin{array}{l}\text { Comparisons (with previous weeks, years, other countries-especially } \\
\text { neighbours and members of the Visegrád Group, or between genders } \\
\text { and age groups) }\end{array}$ \\
\hline Move 3 & Statements from personalities/official sources to enhance credibility \\
\hline Move 4 & $\begin{array}{l}\text { Supporting the information with numbers (percentages, currency, } \\
\text { population, etc.) }\end{array}$ \\
\hline \multicolumn{2}{|c|}{ Optional moves } \\
\hline Move 5 & Cause/effect relationship \\
\hline Move 6 & Future perspective \\
\hline
\end{tabular}

However, the moves can occur in different orders. For instance, in the article "Czech Economy Set to Grow More Slowly", the first piece of information mentioned concerns the predictions of the International 
Monetary Fund regarding the Czech Republic's economy ("The International Monetary Fund (IMF) has offered a worsening outlook for the Czech economy for this year $\left.(. . .)^{\prime \prime}\right)$, corresponding thus to the 6th move, the last to appear in other articles. The moves identified can occur both horizontally (across one paragraph) and vertically (at the text level) simultaneously. I will present conclusions drawn based on random articles and paragraphs from the C-Corpus that will serve as illustrations for the patterns found.

\section{Horizontally}

"[According to the fund] ${ }^{3}$, [the global economy will show 6 percent growth this year] ${ }^{6}$, [while in the autumn, the fund expected growth of 5.2 percent.] 2 " Although short, this paragraph contains the mention of a credible source of information (the International Monetary Fund) corresponding to move number 3 , followed by its predictions for the year 2021 - move 6, and by a comparison with its predictions for the last year move 2 .

Vertically:

This table illustrates how each move is constructed top-down.

Table 3. Examples of moves from different articles

\begin{tabular}{|c|c|c|}
\hline Move & Title of the article & Example \\
\hline 1 & $\begin{array}{l}\text { Škoda Deliveries Fell } \\
19 \% \text { in } 2020\end{array}$ & $\begin{array}{l}\text { Global deliveries by Volkswagen's Škoda Auto fell } \\
19.1 \% \text { to } 1.005 \text { million vehicles in } 2020(\ldots)\end{array}$ \\
\hline 2 & $\begin{array}{l}\text { Prices for New } \\
\text { Apartments in Prague } \\
\text { Rose by } 5.5 \text { Percent }\end{array}$ & $\begin{array}{l}\text { In the EU countries, unemployment in November was } \\
\text { recorded at } 7.5 \% \text {, while in October it was } 7.6 \% \text {. }\end{array}$ \\
\hline 3 & $\begin{array}{l}\text { Czech Banks Will } \\
\text { Start Offering } \\
\text { "Green" Mortgages }\end{array}$ & $\begin{array}{l}\text { As Hospodárské noviny reports, if the property meets } \\
\text { environmental requirements, the applicant could obtain } \\
\text { a cheaper loan. }\end{array}$ \\
\hline 4 & $\begin{array}{l}\text { Prices for New } \\
\text { Apartments in Prague } \\
\text { Rose by } 5.5 \text { Percent }\end{array}$ & $\begin{array}{l}\text { By category, developers sold mostly two-room } \\
\text { apartments, namely } 44 \text { percent. They were followed by } \\
\text { one-bedroom apartments }(23 \%) \text {, three-bedroom } \\
\text { apartments }(22 \%) \text { and four-bedroom apartments }(11 \%) \text {. }\end{array}$ \\
\hline 5 & $\begin{array}{l}\text { Czech Banks will start } \\
\text { offering "green" } \\
\text { mortgages }\end{array}$ & $\begin{array}{l}\text { Since energy efficiency lowers energy use, energy- } \\
\text { efficient homes should have lower bills. This might make } \\
\text { the homeowners less likely to default on their mortgage }\end{array}$ \\
\hline
\end{tabular}




\begin{tabular}{|c|l|l|}
\hline 6 & $\begin{array}{l}\text { Škoda Deliveries Fell } \\
19 \% \text { in } 2020\end{array}$ & $\begin{array}{l}\text { Šyments because their disposable income will be larger. } \\
\text { and its board member responsible for sales, Alain Favey, } \\
\text { said he viewed the coming months with moderate } \\
\text { optimism, despite a surge in COVID-19 infections. }\end{array}$ \\
\hline
\end{tabular}

The table below reflects the moves in a single article, although they are not all present (as the article is very short) and they do not occur in the most commonly identified order.

Table 4. Examples of moves from the same article

\begin{tabular}{|c|c|}
\hline \multicolumn{2}{|r|}{ Czech Government Extends State of Emergency } \\
\hline Move 1 & $\begin{array}{l}\text { The Czech parliament on Friday extended a state of emergency giving the } \\
\text { government extra powers to fight the COVID-19 epidemic until April } 11 .\end{array}$ \\
\hline Move 2 & $\begin{array}{l}\text { Over the past week, the daily cases dropped to 7,600 on average from 12,200 in } \\
\text { early March, when the government introduced a harsher lockdown and } \\
\text { implemented widespread testing at workplaces. } \\
\text { Hospitalisations stood at 7,965 as of Friday morning, down from the peak of } \\
9,462 \text { recorded on March } 15 \text {. }\end{array}$ \\
\hline Move 6 & $\begin{array}{l}\text { Prime Minister Andrej Babiš said on Friday that with the number of new cases } \\
\text { and other figures slowing down, some easing, like pupils' return to schools, } \\
\text { might be possible when the current extension of the emergency state expires. }\end{array}$ \\
\hline Move 3 & $\begin{array}{l}\text { "After Easter, based on the situation, which I am convinced is going in the } \\
\text { right direction, we will announce some dates for reopening of schools and other } \\
\text { measures," he said. }\end{array}$ \\
\hline
\end{tabular}

Here, move 4 (information backed by numbers) is fused with move 2 (the comparisons).

\section{The structure of information}

The structuring of information mostly occurs from general to particular, but depending on the focus in the text, the articles can also feature a particular to general approach. 
"Unemployment Rate in the Czech Republic Lowest in the EU"

Table 5. General to particular structure with examples

\begin{tabular}{|c|l|}
\hline \multirow{5}{*}{ General } & $\begin{array}{l}\text { In absolute figures, Eurostat reports a total of } 15.93 \\
\text { million unemployed in the EU as a whole in November } \\
2020 \text { and } 13.6 \text { million in the Eurozone, with a decrease } \\
\text { of 222,000 and 172,000 unemployed, respectively. }\end{array}$ \\
\cline { 2 - 3 } Particular & $\begin{array}{l}\text { The lowest unemployment rate in November last year } \\
\text { was observed in the Czech Republic }- \text { at } 2.9 \% \text { and } \\
\text { Poland }- \text { at } 3.3 \% .\end{array}$ \\
\hline
\end{tabular}

"Czech Economy Set to Grow More Slowly"

Table 6. Particular to general structure with examples

\begin{tabular}{|c|l|}
\hline \multirow{3}{*}{ Particular } & $\begin{array}{l}\text { The International Monetary Fund (IMF) has offered a } \\
\text { worsening outlook for the Czech economy for this year } \\
(\ldots)\end{array}$ \\
\cline { 2 - 3 } General & $\begin{array}{l}\text { However, in Hungary and Poland, which together } \\
\text { with the Czech Republic and Slovakia form the } \\
\text { Visegrád Four (V4), the monetary fund predicts } \\
\text { inflation even higher than in the Czech Republic. }\end{array}$ \\
\hline
\end{tabular}

“Czech Republic's Economic Level Surpasses Spain, Portugal”

Table 7. Mixed information structure with examples

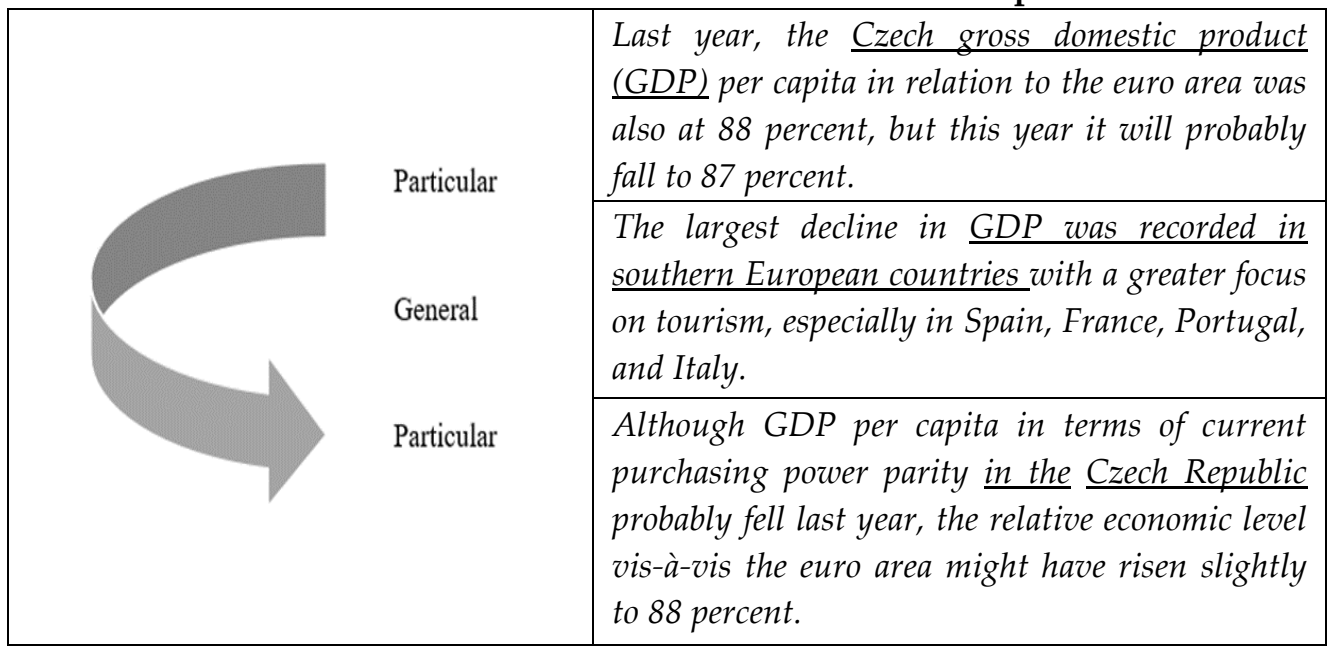


This kind of structure reflects a rather holistic, non-linear thinking characterized by returning to discuss a point which has already been addressed before, and by reaching conclusions based on the whole discussion rather than concluding each individual point, a type of communication specific to East Asian countries (Hiroshi \& Norhayati, 2019).

\section{The micro-structure of articles}

Comparisons with Slovakia

Comparisons with Slovakia (as in the case of the Twitter posts), the other members of the Visegrád Group, and even Russia and China (as mentioned above in the vaccine discussion, emerged several times across the A-Corpus as well, and their appearance across different platforms could be a reinforcement of the connection between language and ideology, as stated by some experts whose views on this matter I exposed earlier.

Table 8. Comparisons with Slovakia in Prague Morning's articles

\begin{tabular}{|l|l|l|}
\hline \multirow{5}{*}{ Title } & $\begin{array}{l}\text { Czech Economy Set to Grow } \\
\text { More Slowly }\end{array}$ & $\begin{array}{l}\text { Slovakia will also perform significantly } \\
\text { worse, as the IMF has downgraded its } \\
\text { growth outlook for gross domestic product } \\
\text { (GDP) for this year to 4.7 percent from the } \\
\text { autumn forecast of } 6.9 \text { percent. }\end{array}$ \\
\cline { 2 - 3 } & $\begin{array}{l}\text { Prague Comes Behind Warsaw } \\
\text { and Bratislava in Ranking of } \\
\text { Financial Centers }\end{array}$ & $\begin{array}{l}\text { In the ranking of world financial centers, } \\
\text { Prague placed behind Warsaw and } \\
\text { Bratislava, as it fell ten ranks to 76th place. }\end{array}$ \\
\cline { 2 - 3 } & $\begin{array}{l}\text { Prague Third Richest Region in } \\
\text { the EU }\end{array}$ & $\begin{array}{l}\text { According to a report issued by Eurostat on } \\
\text { Wednesday, the Czech capital performed } \\
\text { better than Bratislava, Vienna and } \\
\text { Stockholm. }\end{array}$ \\
\hline
\end{tabular}

\section{The use of pronouns}

The first person, plural pronoun "we" appears several times across the A-Corpus, its communicative function being that of bringing the reader into the same discourse category as the authors. Most of the times the pronoun appears in the official statements, suggesting the community of professionals and experts who give their opinion in certain fields, and it is also complemented by the pronoun "our" in some cases. 
Table 9. The use of pronouns in Prague Morning's articles

\begin{tabular}{|c|c|}
\hline Title & Czech Banks Will Start Offering "Green“ Mortgages \\
\hline Experts & 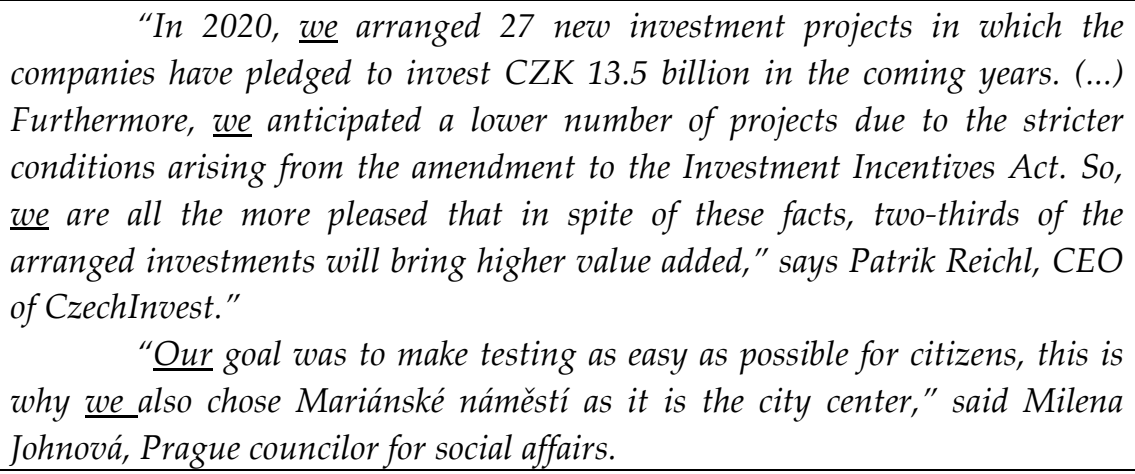 \\
\hline Author & $\begin{array}{l}\text { "Although the concept of green mortgages is no longer a novelty, it is } \\
\text { still too early to predict just how they will work. We are at a very early stage, } \\
\text { and the basic architecture of sustainable finance is still being worked out." }\end{array}$ \\
\hline
\end{tabular}

Reporting verbs

For this purpose, I used the AntConc software (concordance function) to determine the frequency of reporting verbs across all articles and I concluded that the most used one was "said" (28 times), followed by "added" (7 times), "told" (4 times) and "says", "explained" and "claimed", which were used less. Apart from these, the expression "according to" was also employed (28 times) to show the source of information, but as it can be seen, in all cases the author kept an objective perspective, not interfering with the opinions of experts or political authorities and taking the role of the channel through which information only passes unaltered. The figure below shows that the verb "said" is mostly followed by names or positions of experts or politicians. It is also preceded by the source of the statement, being followed by "that" as in the case of "The Health Ministry has said that $(\ldots)^{\prime \prime}$. 
Table 10. The use and frequency of reporting verbs in Prague Morning's articles

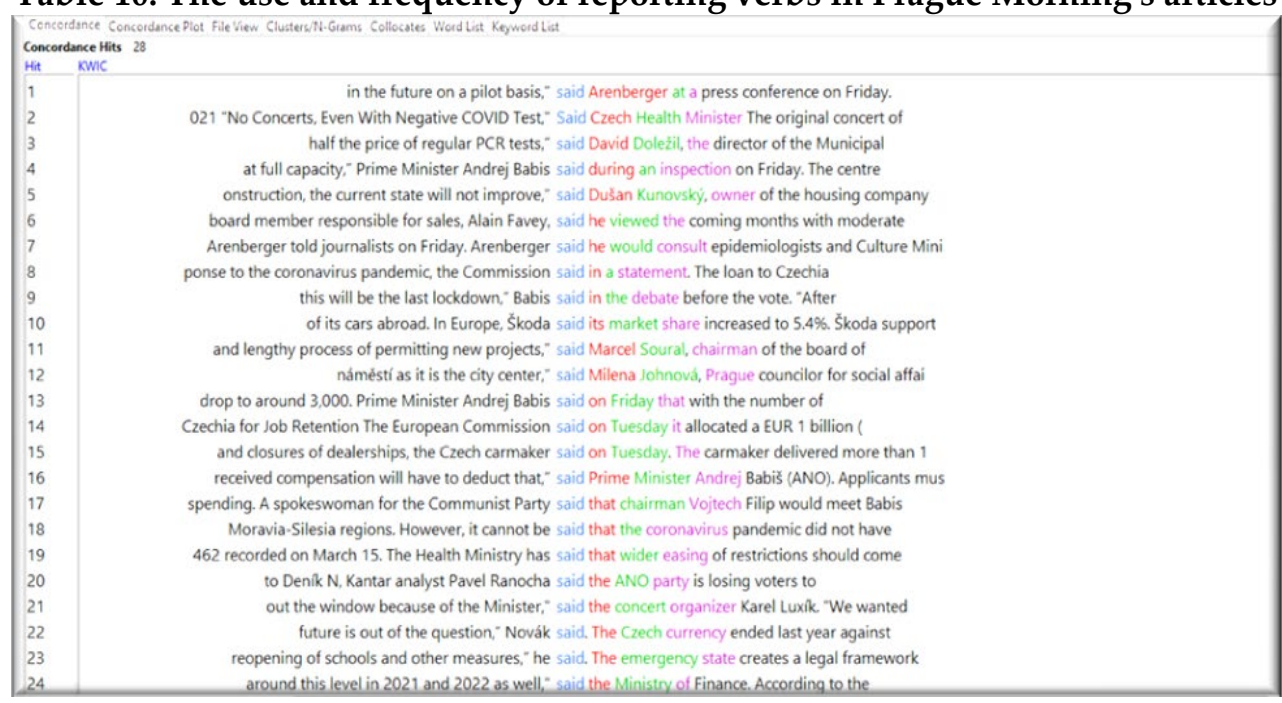

At the same time, "according to" is most of the time used with impersonal sources such as studies, reports, press releases, groups etc.

\section{Prague Morning's articles vs. British articles}

\section{in Muresan's 2000 study}

This sub-section intends to make a parallel between Prague Morning's articles and the economic articles selected by Mureșan (2000) mostly from the Financial Times journal. Due to the fact that their structure and level of complexity are adapted to the audience they address and to the purpose of communication, common and distinct elements can be found. While Prague Morning's purpose is to inform small young foreign audiences (between 200k and 300k readers) about the changes that take place in the Czech Republic and its capital, Financial Times has around 26 million readers every month, most of them being senior members of decisionmaking bodies and influential policymakers, according to Commercial.ft.com.

\section{Dissimilarities}

In comparison to other newspapers and online journals, Prague Morning's articles and sentences are substantially shorter, which could be due to the outlet's efforts to adapt to various levels of language skills among the readers. 
When paralleled with the "Genre analysis and economics" study (Mureșan, 2000), some differences emerge. While Prague Morning's articles can sometimes only have 5 two-line long paragraphs, the British articles are structured along 18 paragraphs. In accordance with their shortness, the website indicates the approximate amount of time that would take the audience to read each article, expressed in a formula such as " 2 minute read".

An article entitled "New COVID-19 Site in Prague Offers Half-Price Saliva Tests" reflects the fact that Prague Morning's articles' shortness and to-the-point character serve the purely informative purpose of keeping the public updated, without giving irrelevant details. That is reflected well in the information provided by an article in which the author compiles pieces of very concise information that may be useful and practical to the public in the context of the pandemic. The entire article includes details about the location, price, the amount of time people would have to wait between the sampling of tests, schedule (between 8 o'clock and 15:30 from Monday to Friday), the number of people that can be tested every day (around 170), the waiting time regarding the results, and even alternative locations (Bulovka University Hospital), warning potential clients that, however, the price there is higher (CZK 1510).

The article "Pro Bono Program Designed to Help Businesses in Prague" contains the rhetorical question "How does it work?", which is probably the author's assumption about the thoughts passing through the readers' minds. It is then followed by practical explanations regarding how the program works, going straight to the audience's point of interest.

At the level of reporting verbs, while in the present study it has been noticed that they are generally neutral ("said", "added", etc.), Mureșan (2000) concludes that in the articles analyzed by her, the reporting verbs reflect the author's intention to convince the audience to accept his/her position in relation to the matters discussed.

Another difference is represented by the examples given within the articles. While Prague Morning does not back its statements up by using examples (it uses absolute numbers and percentages instead - expressed either through the word "percent" or through the symbol "\%"), in the economic articles in the United Kingdom these appear a lot more. 
Table 11. The use of "percent" in articles

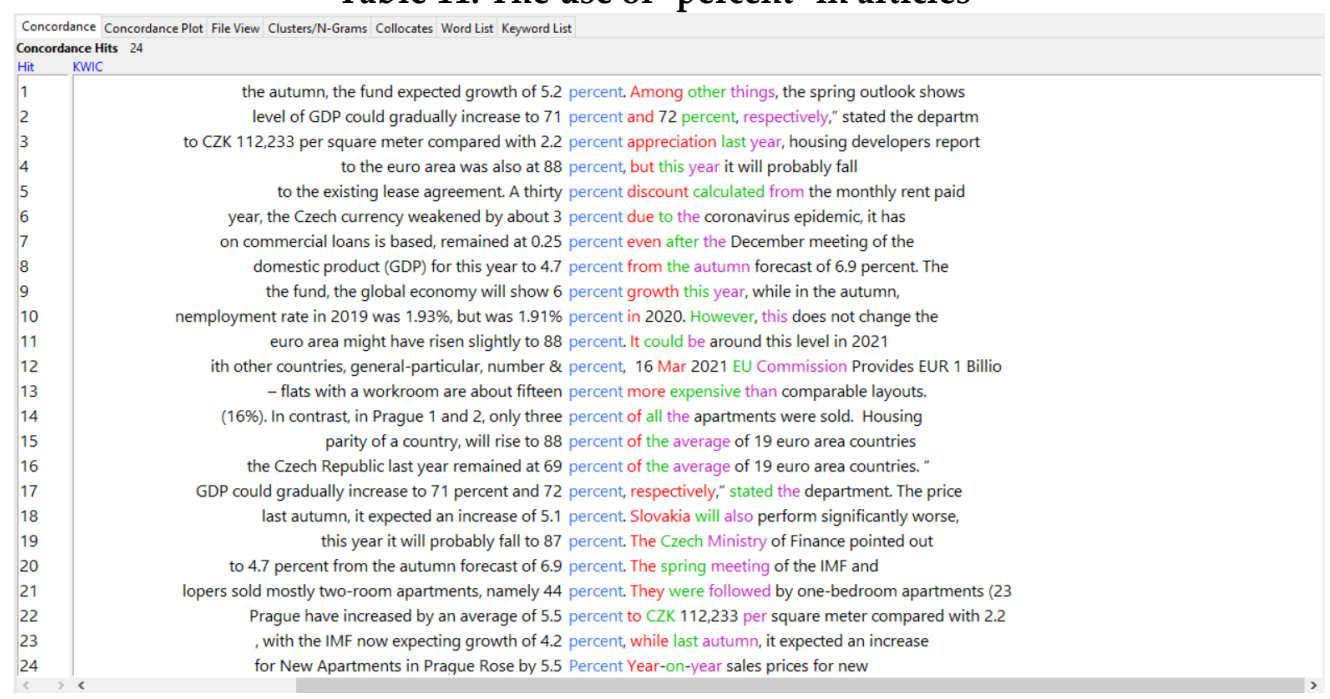

\section{Similarities}

A main element common to both collections of articles is the general to particular structure of information, and in both of them exceptions are possible depending on the focus of the article, usually indicated in the title.

At the linguistic level, the past tense and the passive voice are consistent throughout both batches of texts, means which are usually used to indicate generalizations (Mureșan, 2000). Two examples are found below.

"The program is said to be inspired by findings from other major metropolitan cities like London, where researchers found no evidence of the virus on public transportation." (Prague Morning)

"The years 1980-82 saw surpluses on visible trade which were due both to the impact of North Sea oil and the depressed state of the economy which restrained imports." (British economic articles)

In the same manner, the pronoun "we" is used in all articles, as Mureșan (2000, p. 104) suggests, probably to reduce the "power distance" (in Hofstede's terminology - Hofstede, 1994) between the author and the reader and to place them both in the same "discursive community".

Although the reporting verbs suggest different levels of involvement of the author in the texts, they all report statements of professionals, institutions, and authorities represented by personalities. 


\section{Conclusions}

After observing the rising trends in the field of media and after analyzing Prague Morning's communication patterns, some conclusions can be drawn as to what extent these trends apply to the latter as well as regarding the verification of the initial hypothesis according to which differences emerge in discourse at multiple levels depending on the genre, the author's intentions and on his/her expectations of the audience. The discursive techniques reflect how the language in the media has indeed evolved to resemble a spoken interaction more than a written one, which results in the creation of a more intimate relationship between the author and the readers. On another level, Prague Morning seems to have partially adapted its content to fit consumer demand (as predicted by some experts), as it publishes news considered attractive to the public's interest i.e., current topics such as the evolution of the COVID-19 pandemic, alternative places for recreation (parks), cultural events etc. However, the media outlet does keep a certain amount of originality and spontaneity, as suggested by the use of humour across the news. Another issue addressed in the beginning of the research paper is whether news organizations and social media are complementary or in competition, to which Prague Morning seems to have the first option as an answer, since Facebook and Twitter proved to be efficient platforms for the advertising of its content. At the same time, it showed once again that social media does not (at least not yet) generate new information, as stated in the literature review. As for the validity of the hypothesis, differences did appear based on the channel of communication chosen. Thus, on Twitter, which is a microblogging platform, Prague Morning published synthesized information, while on its official website it published the whole articles. Similarly to Twitter, Facebook was used only to give essential information, the website having to be accessed for the full content. What is also noticeable is that the level of formality in language differs from platform to platform, the articles featuring a solemn and objective tone comparing to Facebook posts and Twitter, where jokes and direct address forms have been made use of. A limitation of the outlet remains the fact that while Facebook offers direct access to the full article by clicking the post, Twitter does not include this facility.

Taking into consideration all the aspects and perspectives discussed above, media remains a broad and complex field which continuously 
changes and which must be treated as a permanently evolving phenomenon, all the more in the context of rising technologies.

\section{References}

1. BLOOR, Th. (1996). Three hypothetical strategies in philosophical writing. In Ventola: E. \& A. Mauranen (Ed.), Academic writing: intercultural and textual issues, (pp.19-43). Amsterdam: Banjamins.

2. BOLER, M., \& Davis, E. (2021). Affective Politics of Digital Media: Propaganda by Other Means. New York: Routledge.

3. Retrieved May 7, 2021 from https://vdoc.pub/documents/affectivepolitics-of-digital-media-propaganda-by-other-means35dh22raio2g

4. FAIRCLOUGH, N. (2000). New labour. New language. London: Routledge

5. GRANATO, L. (2002). Newspaper feature writing. Sydney, NSW: University of New South Wales Press in association with Deakin University Press.

6. HIROSHI, Y. \& Norhayati, Z. (2019). Explanations for cultural differences in thinking: Easterner's dialectical thinking and Westerner's linear thinking. Journal of Cognitive Psycholog

7. HOFSTEDE, G. (1994). Cultures and organizations. HarperCollins: London.

8. LAI, L., \& FARBROT, A. (2014). What makes you click? The effect of question headlines on readership in computer-mediated communication, (pp. 289-299). In Social Influence.

9. MCQUAIL, D. (1994). Mass communication Theory. London: Sage.

10. MURESAN, L. (2000). Genre Analysis and Economics. Bucharest: Paideia.

11. Newman, N. (2011). Mainstream media and the distribution of news in the age of social discovery. Oxford: University of Oxford.

12. O'HALLORAN, K. (2010). How to use corpus linguistics in the study of media discourse. In A. O'Keeffe and M. J. McCarthy (Ed.) The Routledge Handbook of Corpus Linguistics, (pp. 563- 577). London: Routledge.

13. O'KEEFFE, A. (2011a). Media and Discourse Analysis. In Gee, J. \& Handford M. (Ed.), The ROUTLERDGE Handbook of Discourse Analysis, (pp. 441-454). London: Routledge. 
14. O'Keeffe, A. (2011b). The media. In The Routledge Handbook of Applied Linguistics. London: Routledge.

15. PETTY, R., Cacioppo, J., \& Heesacker, M. (1981). Effects of rhetorical questions on persuasion: A cognitive response analysis, (pp. 432-440). Journal Of Personality and Social Psychology

16. ROELE M., Ward, J. \& van Duijn, M. (2021). Tweet with a smile: The selection and use of emoji on Twitter in the Netherlands and England. First Monday.

17. SHAPP, A. (2014). Variation in the use of Twitter and hashtags. New York: New York Universit

18. VAN DIJK, T. (1997). The story of discourse. In T. A. van Dijk (Ed.) Discourse as Structure and Process. London: Sage.

19. ZAPPAVIGNA, M. (2011). Ambient affiliation: a linguistic perspective on Twitter. New media \& society.

\section{Acknowledgements}

This study is based on the bachelor's degree research conducted under the guidance of Prof. Dr. Laura-Mihaela Muresan, whose academic coordination I would like to acknowledge with profound gratitude. I am also highly appreciative of the opportunity of having participated in an Erasmus+ study exchange, from which my inspiration for this study sprang. I would finally like to thank all my mentors, friends and colleagues for inspiring and supporting me throughout the entire process. 